\title{
Whom the gods would destroy they first make mad
}

\section{Dr. Steven McCabe, Associate Professor, Institute of Design, Economic Acceleration \& Sustainability (IDEAS) and Senior Fellow, Centre for Brexit Studies, Birmingham City University}

"Whom the gods would destroy they first make mad" was first used by the Reverend William Anderson Scott' in his book Daniel, a Model for Young Men published in 1854. Its original origin, however, is believed to be much older and likely to be ancient Greece. Intriguingly, in Latin this phrase is usually presented as Quos Deus vult perdere, prius dementat which means, those whom God wishes to destroy, he first deprives of reason.

It's perhaps a sign of the madness of the age we live that we've reached the stage where farmers producing food so essential to our survival are, because of lack of labour, being forced to let crops rot in fields and slaughter animals. The reasons for the shortage of labour is, despite what supporters of the UK's departure from the European Union may claim, a consequence of the of workers not able to come to the UK due to the ending of freedom of movement.

Writing last month, Pugh describes difficulties British farms are having in recruiting sufficient seasonal agricultural labour. There are calls made by the National Farmers' Union for greater assistance by the Government (2021). Pugh cites a number of examples of how farmers are coping.

One, Cartwrights, who've been farming at Home Farm, Condover, near Shrewsbury, since the 1930s and produce potatoes, wheat, barley, oats and oil seed rape as well as rearing KellyBronze turkeys, have experienced difficulties this year which have been overcome though there are concerns for the future. David Cartwright, interviewed by Pugh, accepts that because of the Seasonal Worker Pilot used this year, he'll be able to save his output but, ominously, suggests a continued absence of British workers willing to work on farms may result in him investing in robotics:

"I will be looking into robotics to help with the potatoes. It will be a $f 100,000$ investment but it will replace two people."

Undoubtedly increased investment will be regarded by government as a good thing as it will contribute to British productivity which, simplistically, is the value of output divided by the number of workers (Chew, 1988). However, as well as increasing the need for investment by hard-pressed farmers, it will mean fewer more indigenous citizens employed should such investment occur in other sectors.

This is hardly likely to make people richer as advocates of Brexit claimed it would.

If the shortage of fuel was last week's pervading crisis, and still remains so in certain parts of the country, particularly the south-east, this week's crisis is pigs.

As Driver (2021) makes clear in his article for PigWorld, 'the voice of the British pig industry', there's anger among those producers at what's seen as an arrogant Prime Minister willing to throw the "crisis-torn industry under a bus".

Referring to Boris Johnson's 'car crash' interview with the BBC's Andrew Marr on Sunday, ahead of the Conservative Party conference in Manchester, Driver describes his response to a question put to him that 120,000 pigs will need to be slaughtered and incinerated within ten days because of shortage of abattoir and butchery workers.

Driver specifically references Boris Johnson's comments that "uncontrolled immigration" has been part of the problem. Indeed, as suggested by members of the government on Tuesday, too many 
businesses have become 'drunk on cheap labour' and a number of ministers used speeches in Manchester to criticise firms who they believe perceive as attempting to "shift blame on to the Government" (Rayner, Riley-Smith and Yorke, 2021).

Fascinatingly, we appear to be in a 'blame game' of sorts as, in this article, a 'senior source' is quoted as stating, "a failure of the free market, not the state" is the reason we're seeing the crisis of fuel shortages, problems on British farms and, increasingly as far as some products are concerned, empty shelves in shops and supermarkets.

In the strange times we're living in, certain key members of the Conservative Party start to sound more socialist than current leader of the Labour Party, Sir Keir Starmer, who's desperate to delineate himself from the aberration he clearly thinks the 'Corbyn era' was. Interviewed on BBC's Breakfast programme on Tuesday, Johnson argued that what we are experiencing is due to the "old, failed model where you mainline low-wage, low-skilled labour - very often very hard-working, brave, wonderful people - who come in, working in conditions that frankly are pretty tough, and we shouldn't be going back to that."

Significantly, and consistent with what appears to be choregraphing of messages from government, Johnson, when interviewed by Nick Robinson on Tuesday morning's BBC Radio 4 programme, Today, categorically stated his belief that there's "no" crisis currently and difficulties were due to the economy recovering after the massive slowdown caused by the pandemic, like a "a giant waking up".

Some are not impressed by the message. The Daily Mail, normally supportive of the Conservative Party, makes clear its exasperation at the PM's statement that the chaos being experienced is "part of his plan" and his claim, to GB News, that it's not the job of government to "come in and try and fix every problem in business and industry" (Tapsfield, 2021). As well as being critical of the PM for dismissing the threat posed by rapidly rising inflation, Tapsfield cites his somewhat peculiar statement that despite all of the problems and though "we have fantastic supply chains [and] fantastic logistics,", "there is a problem of demand."

Clearly consumers should be prepared to take their share of the blame.

Johnson, clearly buoyed by opinion polls which, broadly, show his support is holding firm and there's been no 'bounce' for Starmer following his speech to the Labour Party last week, - it was notable he specifically criticised 'Captain Hindsight' in his interview with Nick Robinson - feels secure. Because of Covid-19, which he was memorably hospitalised by, this is Johnson's first party conference since winning the general election held in December 2019, when he asked voters to support his "ovenready deal" to achieve Brexit.

As we're discovering, yet again, and despite having been part of the negotiation team who agreed the Northern Ireland Protocol with the EU last Christmas Eve, Lord Frost in a speech to the party faithful in Manchester is threatening to unilaterally suspend its operation (Foster et al, 2021). It's highly likely that this is a deliberate tactic to use conflict with the EU to divert attention away from domestic issues currently confronting the government.

As the history of all-powerful leaders shows, danger inevitably lie ahead. Even in the moment of triumph and adulation it's important to recognise how limited your time in control may be. It's believed that when generals returned to ancient Rome after having won battles, they were to be accompanied by a slave whose only task was to continually whisper, "Memento mori," meaning "remember you will die". 
Equally, Johnson, regardless of any sense of invulnerability in having, for now, seen of the threat posed by his former chief political advisor, Dominic Cummings, should heed the warning to keep his friends close and his enemies closer. Indeed, as is widely reported many of those who supported him within his own party are coming to the conclusion Johnson has outlived his usefulness in having achieved the cherished goal of Brexit and the party should now be led by a 'proper Conservative' believing in financial rectitude (Morgan, 2021).

More particularly, many business leaders are questioning Johnson's approach to labour shortages being experienced in a number of sectors. Johnson's statements that business, and not the government, is to blame for problems being experienced, is creating new foes. These should worry him.

Next chief executive and Tory peer Lord Wolfson, regarded as one of the most ardent supporters of Brexit, has denounced the PM's post-Brexit immigration policy which he contends is causing "chronic" problems for hospitality, care homes, hospitals, agriculture and warehouses (Woodcock, 2021).

Lord Wolfson, in an article written the Evening Standard is contemptuous about Johnson's argument to business that the way to solve the problem of labour shortages is to simply pay British workers more. This, he believes, will "only result in a Seventies-style inflationary spiral" (2021).

Resonant with what I wrote last week in my blog, Lord Wolfson stresses the vote to leave was one allowing the UK to determine its own immigration policy. Any alternative system, he argues, was not predetermined when the referendum took place in June 2016. What has been decided is based on Johnson's perspective of what Brexit should mean and, significantly, one entirely different to that envisaged as part of the deal formulated by predecessor Theresa May which incorporated the needs of business.

Lord Wolfson's solution is elegantly simple:

"The answer is to create a demand-led system, that allows the needs of our economy to pull in the talent we really need. For example, why not allow businesses to sponsor as many work visas as they need, with two vital caveats: firstly all overseas workers must receive the same pay as their UK colleagues and secondly, businesses must pay a percentage (say seven per cent) of overseas workers' wages to the Government as a visa tax."

Though Lord Wolfson is unlikely to lead any protest, others appear willing to do so.

Driver (ibid), who states that in over 20 years of reporting he has never "never seen such an appalling, ill-judged and ill-informed interview" as that by Johnson on the Marr show, and that it's "astonishing that it came from a man deemed worthy by some of holding the role of Prime Minister", believes the mood among pig farmers is restless.

Driver believes that should there be no resolution to the crisis through facilitating a short-term temporary visa arrangement for butchers from the EU, militancy similar to that used by French farmers, will become likely. As he warns, should the Government continue to "sacrifice the British pig sector in pursuit of wider ideological goals" there will be repercussions:

"This proud industry will not take it lying down. It will, as it has done in the past, fight for its future. The Government is going to learn more about how the pig industry feels over the next few days."

In the meantime, sadly, chaos will continue. 
Clearly, those in the case of Johnson, the 'Brexit Gods' have ensured he's deprived Boris Johnson of both wisdom and reason. However, in the tradition of the British comedy films of yesteryear, we should expect him to carry on 'governing'!

Dr. Steven McCabe is co-editor of Exploring the Green Economy, Issues, Challenge and Benefits published by Bite-Sized Books (ISBN-13 979-8532032347) and is currently working on companion text, Green Manufacturing, What this involves and how to achieve success, which is due to be published to coincide with the Cop26 climate conference in Glasgow. He's also working on a text examining how to solve Britain's house price problem. His chapter 'Al Promised You a Miracle - Life Under 'Greased Piglet' Johnson', is included in Populism and the Media, published by Abramis Academic in June.

\section{References}

Chew, W.B. (1988), 'No-Nonsense Guide to Measuring Productivity', Harvard Business Review, January, https://hbr.org/1988/01/no-nonsense-guide-to-measuring-productivity, accessed 5th October

Driver, A. (2021), 'Industry fury as arrogant Prime Minister throws crisis-torn pig industry under a bus', Pigworld, 3rd October, https://www.pig-world.co.uk/news/industry-fury-as-arrogant-primeminister-throws-crisis-torn-pig-industry-under-a-bus.html, accessed 5th October

Foster, P., Fleming, S., Webber, J. and Mallet, V. (2021), 'Brexit minister Frost threatens to suspend part of Northern Ireland deal with EU', Financial Times, 4th

October, https://www.ft.com/content/f0724b34-f1f9-4c3c-9646-fb0c2bbec952, accessed 5th October

Morgan, P. (2021), 'Mark my words: Rishi Sunak will replace Boris Johnson as PM sooner, not later', DailyMail Online, 11th September, https://www.dailymail.co.uk/home/event/article-

9977249/PIERS-MORGAN-Mark-words-Rishi-Sunak-replace-Boris-Johnson-PM-sooner-notlater.html, accessed 5th October

Pugh, J. (2021), 'Farms continue to face shortage of seasonal labour', Shropshire Star, 22nd September, https://www.shropshirestar.com/news/farming/2021/09/22/farms-continue-to-faceshortage-of-seasonal-labour/, accessed 5th October

Rayner, G., Riley-Smith, B. and Yorke, H. (2021), 'Businesses have become 'drunk on cheap labour', say Tories', Telegraph, 5th October, https://www.telegraph.co.uk/politics/2021/10/04/businesseshave-become-drunk-cheap-labour-say-tories/, accessed 5th October

Tapsfield, J. (2021), 'Boris says it is 'not my job to fix all of the UK's problems': PM's astonishing claim as he denies nation is in 'crisis' and DISMISSES inflation spike fears, fuel shortages and empty supermarket shelves as "just part of his new approach", DailyMail Online, 5th

October, https://www.dailymail.co.uk/news/article-10060043/Boris-denies-claims-supply-chainchaos-just-ending-UKs-low-wage-economy.html, accessed 5th October

Wolfson, L. (2021), 'Next CEO Lord Wolfson: I voted for Brexit but as the head of a FTSE 100 company I know more than anyone how much Britain needs immigration', Evening Standard, 4th October, https://www.standard.co.uk/comment/lord-wolfson-brexit-next-immigration-governmentvisas-hgv-tory-b958610.html, accessed 5th October

Woodcock, A. (2021), 'Pro-Brexit Tory peer hits back at Boris Johnson's attempt to blame business for labour shortages', Independent, 4th 
October, https://www.independent.co.uk/news/uk/politics/brexit-labour-shortage-lord-wolfsonb1931913.html?r=63950, accessed 5th October 